\title{
MANAGEMENT PROCESSES AND STRATEGY EXECUTION IN FAMILY FIRMS: FROM "WHAT" TO "HOW"
}

\author{
James J. Chrisman \\ Mississippi State University \\ and University of Alberta \\ jchrisman@business.msstate.edu \\ Jess H. Chua \\ University of Calgary \\ Lancaster University \\ and Zhejiang University \\ jess.chua@haskayne.ucalgary.ca
}

\author{
Alfredo De Massis \\ Free University of Bozen-Bolzano \\ and Lancaster University \\ a.demassis@lancaster.ac.uk \\ Tommaso Minola \\ University of Bergamo \\ tommaso.minola@unibg.it \\ Silvio Vismara* \\ University of Bergamo \\ and University of Augsburg \\ silvio.vismara@unibg.it
}

\footnotetext{
* Corresponding author
} 


\title{
Management Processes and Strategy Execution in Family Firms: From "What" to "How"
}

\begin{abstract}
The distinctiveness of family firms' goals, structures, resources, strategies, and performance has been studied in terms of what family firms do or are able to achieve that are different from those of nonfamily firms. This dominant approach to studying family firm behavior has contributed significantly to our understanding of such organizations. Currently, however, we know little about how family firm decisions are made and the processes by which family firms plan and execute. We develop a conceptual framework and set out an agenda for future research on how the distinctive/unique interaction between the business and the family influences the management processes by which family firms implement their strategies.
\end{abstract}

Keywords: family firms; family business; process; strategy execution; family willingness; family ability.

JEL classification: D21; L21; L26. 


\section{INTRODUCTION}

Family business studies has emerged as a distinctive field of scholarship over the last two decades (De Massis, Sharma, Chua and Chrisman, 2012; Melin, Nordqvist and Sharma, 2013). The field still faces developmental challenges, however, in terms of knowledge consolidation, increasing rigor, and relevance (Steier, Chrisman and Chua, 2015; Wright, Chrisman, Chua and Steier, 2014). Making richer contributions to general management and economics requires efforts such as theoretical reconciliation with general business theories, conceptual and empirical elaboration of the heterogeneity of family firm types, and theoretical refinement of the sources of family firm distinctiveness. Such maturation may be achieved through insightful and comprehensive investigation of the micro-foundations of family firm behavior (Gagné et al., 2014), in particular the unique actors in and actions of the family firm.

There is an evolving consensus that family firm actors are characterized by distinctive intentions, motivations, and discretion and their actions are a consequence of distinctive goals, governance structures, and resources (Chrisman et al., 2013; De Massis, Kotlar, Chua and Chrisman, 2014). For example, empirical evidence points to the distinctive nature of family firms in terms of internationalization (George et al., 2005), entrepreneurship (Zahra et al., 2004), innovation (De Massis et al., 2013), diversification (Gómez-Mejía, Makri and Larraza-Kintana, 2010) and financing (Chua et al., 2011). These areas of distinctiveness have been studied by contrasting what family firms do or are able to achieve with nonfamily firms. This dominant approach of studying what characterizes family firm behavior and to what extent, or where family firms are different from nonfamily firms has contributed significantly to our understanding of the family form of organization (De Massis et al., 2012). Currently, however, we know very little about how decisions are made and the processes by which family firms 
produce their distinctiveness. For example, out of the most highly cited 215 family business studies published between 1996 and 2010, only 18 revolved around how-type research questions (De Massis et al., 2012). Without understanding the processes by which family firms execute their strategies it will be difficult to determine to what extent family firm behavior and performance are functions of idiosyncratic goals, idiosyncratic governance structures, idiosyncratic resources, idiosyncratic strategies, or idiosyncratic processes. ${ }^{1}$ Yet, such deepened understanding will be very important for both developing a theory of the family firm and helping family firms improve their performance and contributions to the economy.

Recently, family business researchers have emphasized that family firms will not produce behaviors and performance different from those of nonfamily firms unless the family has both ability and willingness to act in an idiosyncratic fashion (e.g., Chrisman, Chua, De Massis, Frattini and Wright, 2015; De Massis et al., 2014). But even with power to act unilaterally, willingness to act that way, and resources needed to carry out the chosen plans of action, family firms may still not produce distinctive behavior if they cannot execute.

Execution is done using management processes by which we mean: how the organization identifies decisions that must be made and tasks that must be completed to resolve issues and problems; how it sets objectives; how and to whom decisions and tasks are assigned or delegated; in what sequence the decisions are made and actions taken; and the accountabilities and deliverables demanded from organizational actors. Considering that the controlling family's involvement will necessarily introduce family goals and dynamics into the organization and organizational processes, the management processes adopted by family firms can be expected to be distinctive as well.

\footnotetext{
${ }^{1}$ The family business literature uses three different adjectives (distinctive, idiosyncratic, and particularistic) to describe the differences between family and nonfamily motivations, behavior, resources, and performance. We use them interchangeably here although we realize that they are not strictly equivalent.
} 
The purpose of this special issue is to help foster studies on how the unique interaction between the business and the family influences the management processes adopted by family firms. The special issue called for contributions that: (i) present quantitative or qualitative evidence of differences in the management processes adopted by family firms and nonfamily firms or those adopted by different types of family firms; and (ii) are able to provide rigorous explanations about why the differences exist. Following the call, 17 papers were submitted and, after completing several rounds of the standard double blind review process, five were accepted for publication in this special issue of Small Business Economics.

To put these articles in the proper context, to help stimulate research in this important direction, and to help researchers identify the relevant research questions that need to be considered in the future, we present below a framework for studying the "how" of family firm behavior.

\section{A FRAMEWORK FOR “HOW"}

Our framework proposes that management processes employed by family firms will be different from those of nonfamily firms because family involvement motivates the family's behavioral propensities in terms of ability and willingness to pursue particularistic goals. This leads to the adoption of particularistic governance structures and accumulation of particularistic resources which comprise the strategic drivers of family firms' management processes. Therefore, it is our opinion that we must understand the nature of family involvement, the behavioral propensities of the controlling family, and the strategic drivers before we will be able to comprehend family firms' management processes.

\section{Family involvement}


The notion that family involvement affects strategic decisions (Sharma and Manikutty, 2005; Minola et al., 2017), organizational processes (Chrisman et al., 2008), and firm performance (Kowalewski, Talavera, and Stetsyuk, 2010; Memili et al., 2015) is not new. However, the effects of family involvement, by itself, are unclear and empirical results concerning them are conflicting (O'Boyle et al., 2012). This suggests that the relationship between family involvement and firm behavior is quite complex likely due to family involvement's diversity and multidimensionality (Chrisman et al., 2008).

Some scholars drawing, for example, on the F-PEC scale (Klein et al., 2005) propose that power (through ownership, management and governance) and experience (the number of generations that have been involved in developing the family firm) determine the nature of family involvement. Recently, however, family business researchers argue that family involvement is a necessary but insufficient condition for family firms to behave in a distinctive way, meaning that family involvement is insufficient to directly determine family firm behavior unless we take into account the behavioral propensities of the involved family. (Chrisman, Chua, Pearson, and Barnett, 2012; De Massis et al., 2014; Chrisman et al., 2015).

\section{Behavioral propensities of the involved family}

The involved family's behavioral propensities consist of the family's ability and willingness to engage in distinctive behavior. Ability and willingness comprise the behavioral propensities of family firms because they affect the family's choices of the strategic drivers leveraged to produce distinctive behavior. $^{2}$

Ability, defined as the discretion of the family to direct, allocate, add to, or dispose of a firm's resources, can be measured by family ownership, family board membership, and family

\footnotetext{
${ }^{2}$ De Massis et al. (2014) present a comprehensive review of correlates and measures of both ability and willingness constructs.
} 
management. Willingness, defined as the favorable disposition of the involved family to engage in distinctive behavior, has been attributed to transgenerational succession intentions, socioemotional wealth concerns, and commitment to the business (Chrisman et al., 2012; Gómez-Mejía et al., 2007). It is related to, but does not necessarily accompany, family involvement (e.g., Litz 1995). Even with the same extent of family involvement, for example, family members' personal attachment to the firm, self-identification with the firm, intention for intra-family succession, and desire to preserve socioemotional wealth can vary (Berrone et al., 2012; Chua, Chrisman and De Massis, 2015; Schulze, Lubatkin, and Dino 2002, 2003). Thus, Chrisman and Patel (2012) show that irrespective of the extent of a family's involvement, the importance of the transgenerational sustainability of control can vary among family firms, and that this variation produces heterogeneous investments in research and development. This is consistent with prior research based on the "essence” approach (Chrisman et al., 2005) which assumes that, in addition to the family's ability determined by family involvement, an intention to pursue a particularistic vision across generations of the family is necessary to make the firm behave and perform in a way that differs from nonfamily firms (Astrachan, Klein, and Smyrnios, 2002; Carney, 2005; Chua et al., 1999). The need for considering willingness as well as ability is also consistent with other studies that assume family members' identification of the firm as a family firm (e.g., Deephouse and Jaskiewicz, 2013; Westhead and Cowling, 1998) influences the family firm's distinctive behavior (Zellweger, Eddleston, and Kellermanns, 2010). This proposal (De Massis et al., 2014) that family-oriented idiosyncratic goals are pursued to the extent that the family involved in the business has both the ability and the willingness to pursue such ends seems intuitively obvious but has been overlooked in family business research, resulting in theoretical limitations and empirical indeterminacies (De Massis et al., 2014). 


\section{Strategic drivers of family firms}

Following Chua et al. (2012), we group the strategic drivers that family firms must leverage to produce distinctive behavior into goals (Chrisman et al., 2012), governance structures (Carney, 2005), and resources (Habbershon, Williams, and MacMillan, 2003).

Goals in family firms are widely believed by researchers to be both economic and noneconomic in nature (Chrisman et al., 2012) and are a major cause of heterogeneity among these firms (Chua et al., 2012). Although the process through which these goals emerge and are collectively determined is quite complex (Kotlar and De Massis, 2013), the distinctive strategic goals of the family firm arise as a result of the involved family's ability and willingness. For example, firms with family involvement would not have the ability to pursue family-oriented goals such as family harmony, family social status, and family identity linkage (Chrisman et al. 2012; Kotlar and De Massis, 2013) that create or preserve socioemotional wealth (Gómez-Mejía et al., 2007) if there are influential nonfamily shareholders who object. Obviously, if the family is not willing to pursue these family-oriented non-economic goals, instead focusing entirely on economic goals, then the non-economic goals will not be pursued.

In the same vein, the family's ability arising from family involvement generates differences in governance (Astrachan et al., 2002; Klein et al., 2005). The family's organizational authority resulting from the family's power and legitimacy is defined by prevailing cultural, political, regulatory, competitive, and capital market conditions (Carney 2005; Chua et al., 1999). The family's exercise of its ability to govern the firm may lead to the board of directors (BOD) being entirely controlled by family members or ownership involving pyramids, cross-holdings, and dual voting class shares (Claessens, Djankov, and Lang 2000) that allow the family to bypass the board when making strategic decisions (Carney 2005; Lorsch and 
MacIver 1989). In other words, latitude in strategic decisions concerning how firm resources are developed, deployed, and shed depends on the organizational authority of the involved family. For instance, the family may be able to constrain managerial actions without being directly involved in the top management team by reducing the resources available to them (Finkelstein and Hambrick 1990; Hambrick and Finkelstein 1987). Thus, willingness and ability determine the strategic goals of the organization, the governance structures that will be adopted as well as the tangible and intangible resources that the involved family will be able to access, direct, allocate or use (De Massis, Di Minin and Frattini, 2015) ${ }^{3}$. It is also important, however, to note that the most important and enduring resources of a family firm are those embedded in the human, social, and emotional capital of the family members.

\section{Execution in family firms}

To achieve its goals, the family firm's dominant coalition will leverage its governance systems and resources to influence all aspects of a firm's organization and activities (Argote and Greve, 2007), particularly its strategy and execution (e.g., Hambrick and Mason, 1984). Existing family business research assumes that once strategy is defined, successful execution follows. This is, however, not always the case; the extent to which the execution follows and serves a particular strategy, and the extent to which such execution will lead to distinctive outcomes, depends on the family firm's capacity to execute. Different abilities in this respect can produce different results despite similar family involvement configurations. In other words, the same strategy can be executed in different ways (De Massis, Kotlar, Frattini, Chrisman, Nordqvist, 2016); some will succeed and some will fail. This means that, without understanding the management processes by which family firms execute their strategies, it will be difficult to determine to what extent

\footnotetext{
${ }^{3}$ It is worth noting that, as illustrated in Figure 1, we have assumed a hierarchy among goals, governance and resources. Consistent with the strategic management perspective, we assume that goals are the guiding factor of governance, and goals and governance in turn set the conditions for the use of resources.
} 
their behavior or performance is a function of idiosyncratic strategic goals, idiosyncratic governance structures, idiosyncratic resources or the failure to execute.

Family firm's execution has not received as much attention in scholarly discourse even though execution is particularly relevant and pertinent as it complements strategy research and can be a source of family firm heterogeneity (Chua et al., 2012). Rare examples include DeTienne and Chirico (2013) and Wiklund et al. (2013), who show how family involvement leads family owners to choose between control retention and divestment, and Carnes and Ireland (2013) who conceptualize a relationship between family goals, resources, and resource-bundling processes that explains firm strategic decisions about innovation.

\section{Family involvement and management processes}

Management process may be simplified to consist of five components, namely: (1) required tasks; (2) actors; (3) assignment/delegation of tasks; (4) sequence of actions; and (5) accountabilities and deliverables. Every strategy requires the performance of a set of tasks in order to implement that strategy and these tasks are shaped by the goals, governance, and resources of the dominant coalition of decision makers in an organization. In family firms the non-economic goals of the dominant coalition simultaneously limit and extend the possible range of tasks that can be used to implement the strategy. For example, emotional attachment makes it difficult for some family firms to shed resources (Sharma and Manikutty, 2005) but the relative absence of end-game scenarios may increase their ability to entrepreneurially manage those resources and identify new opportunities (Kellermanns, 2005; Patel and Fiet, 2011). Similarly, family governance may lead to conservation and conservatism in the tasks that are performed. On the other hand, family governance may also brook less opposition, meaning that tasks can be performed without delay (Carney, 2005; König, Kammerlander, and Enders, 2013). Finally, the 
resources embedded in the firm through family involvement will also create limits and opportunities for strategy execution, ${ }^{4}$ particularly with regard to the presence or absence of bifurcation biases in the use of family and nonfamily human capital (Verbeke and Kano, 2012).

Family firms can execute using a differentiated set of actors whose effectiveness will strongly influence firm outcomes. Within the dominant coalition the family principal holds major control on the firm and its activities; therefore, other family members are often involved - be they from subsequent generations of the family, i.e. offspring, or from other family branches. Given the heterogeneity of positions and roles of these actors within the family system, aspects like cognitive and affective distance, personal and group-related developmental concerns, and experience within the firm are likely to affect individual's capability to execute (Jennings et al., 2013). They will also determine the extent to which actors' execution is effectively orchestrated to yield firm outcomes (Gersick et al., 1997). On the other hand, nonfamily members are also important executors of organizational actions and tasks. They normally represent a check on the controlling family’s discretion and are needed for firm professionalization (Chua et al., 2009; Colombo et al., 2014), both of which are potentially beneficial to the firm. For these actors (be they owners, managers or board members) to make effective contribution, however, appropriate governance structures need to be established (Guidice et al., 2013).

Delegation of tasks allows leaders to focus on strategic issues, creates a feeling of ownership among subordinates, and puts decision making in the hands of individuals with the most information. As such, it enhances firm's effectiveness, as well as subordinates' satisfaction (Chen and Aryee, 2007). It is, however, a challenging task for family firm principals because it may conflict with their overriding desire to maintain control. Thus, delegation is strongly

\footnotetext{
${ }^{4}$ We use the term "strategy execution" here instead of the more commonly used "strategy implementation" to emphasize that this is about how because the latter tends to be applied in a sense that is most frequently about what are or need to be done and only occasionally about how.
} 
affected by the degree to which the dominant coalition is gratified by tight control of family operations (Berrone et al., 2012). The level of human capital among family and nonfamily employees, as well as the extent to which bifurcation bias operates, will also affect the effectiveness of delegation practices in terms of firm outcomes (Chua et al., 2009; Verbeke and Kano, 2012).

In management processes, actors undertake actions in specific sequences (Van de Ven, 1992). Sequencing of actions is important as it can determine the effectiveness of a process (Amis et al., 2004). For example, Romanelli and Tushman (1994), in studying organizational change processes, indicated that the outcomes of such processes vary when the actions performed are sequenced rather than simultaneously enacted. Interest in the sequencing of management processes and its impact on their outcomes has surged, but this area continues to be under-theorized (Liguori, 2012). The need to account for sequencing of management tasks derives from the fact that all elements of an organization are not neutral and value-free. Conversely, actors establish objectives, meaning and interpretive schemes, which affect their beliefs and consequent alignment to strategy execution. Since such beliefs are not attached to all organizational elements equally, the order in which different elements are altered or manipulated will affect the outcome. This is even more pronounced in family firms, where temporal sequence of actions mirrors the priorities and goal hierarchies of actors (Paul et al., 2003). For example, execution might be different when a bottom-up approach is preferred (defining operational tasks before determining execution of higher order coordination tasks) to top-down approach (defining the overall framing and architecture of the process first and operational tasks follow). Similarly, information processing and task alignment could be oriented by multitask execution, when different actions are undertaken in parallel, and the actor has to ensure coordination of different 
sub-processes, each with its own pace, rather than in a linear and serialized fashion (Amis et al., 2004). Moreover, in family firms the temporal evolution of both the family and the business systems (De Massis, Chirico, Kotlar and Naldi, 2014; Minola et al., 2017) adds further complexity to the sequencing of actions required to execute strategy.

Organizational controls and monitoring are needed, in support of the strategy execution process, to help firms perform the tasks required to achieve their desired outcomes. Accountabilities, a subject's obligation to report, explain, or justify something, and deliverables, the object of accountability, provide formal mechanisms for information-based controls. They are relevant to strategy execution because they allow firm principals to validate and legitimize their strategies, to communicate the value of such strategies to internal and external stakeholders and - most importantly - to enact change by inducing actors' responsibility and facilitating corrective actions (Hitt et al., 2012). In other words, accountabilities and deliverables help move forward the execution of the strategic plan, on the one hand, and support strategic leadership, on the other. An overlooked aspect of family firms' execution effectiveness is their ability to hold their family managers accountable for behaviors and deliverables (Chua et al., 2009; Lane et al., 2006). This is an especially interesting research topic as family status is likely to play a role in shaping accountability procedures and perceptions. Effective strategy execution, in fact, requires not only formal mechanisms of monitoring to be put in place, but also considerations about how these mechanisms interact with complex interpersonal ties (Jennings et al., 2013). In particular, actors' identity, organizational norms, and personal perceptions of behavioral control are among the elements that determine how managers perceive themselves as accountable and how they respond to strategy execution efforts (Guidice et al., 2013). Given the uniqueness of the social and psychological context of family firms, understanding accountabilities and their effect on 
strategy execution is a valuable complement to theoretical efforts aimed at explaining how family firms function.

To summarize this discussion, Figure 1 presents the framework of the logical chain leading from family involvement to management processes. As shown, the family firm's behavioral propensities consist of ability and willingness. Ability is connected to family involvement by a solid arrow because discretion flows directly from involvement in ownership, governance, and management. On the other hand, willingness to engage in idiosyncratic behavior is not necessarily a function of the level of family involvement, as shown by the dashed arrow.

Insert Figure 1 about here

The strategic drivers flow out of the behavioral propensities, willingness mainly affecting the goals pursued and ability primarily affecting governance and resources. ${ }^{5}$ The firm's strategies must be executed by employing management processes that are defined by the required tasks; the actors; the assignment/delegation of tasks; the sequence of actions; and the accountabilities and deliverables. Out of the management processes will then flow the firm's performance in terms of both economic and non-economic goal achievement. Under- or over-performance when compared with the aspiration level flowing from the goals may then lead to revision of the strategic drivers, behavioral propensities, or even family involvement. In the next section, we summarize and position the papers in this special issue according to our proposed framework of how family involvement in business influences the management processes by which family firms execute.

\section{THE ARTICLES IN THE SPECIAL ISSUE}

\footnotetext{
${ }^{5}$ Conceptually, both ability and willingness influence all three drivers. Partly for emphasis and partly to avoid cluttering the figure, we chose to focus on the most important influences.
} 
The papers accepted for this special issue, together with future research directions, were selected to help move family business research from "what" to "how" by what we hope will be a starting point for family business scholars to develop a deeper understanding of management processes in family firms.

\section{CEO Type and Board Behaviors}

Prior work has generated conflicting findings on whether boards of directors (BOD) influence family firm performance (Bammens, Voordeckers, and van Gils, 2011). Based on upper echelon theory, Zona (2016, this issue) argues that this may be caused by differences in board processes and that different types of CEOs will benefit dissimilarly from different board processes. Within the family firm, the differences in impact would likely be most substantial between family CEOs and nonfamily CEOs. Since nonfamily CEOs are generally more competent and professional, he suggests that the degree to which board members are able to coordinate their knowledge and skills will have a greater positive impact on the board's performance when a family firm is managed by a nonfamily CEO. On the other hand, when a firm is managed by a family CEO, board performance will be increased more to the extent the board engages in cognitive conflict. He claims that family CEOs are prone to risk aversion, strategic inertia, and concerns for socioemotional wealth and therefore cognitive conflict on the part of the board can engender more cogent and comprehensive analyses and foster innovation. Finally, Zona proposes that owing to information shortcomings, when family CEOs are at the helm, greater effort by directors will have a stronger association with board performance than when nonfamily CEOs, who have greater access to outside information, are in charge.

Zona uses hierarchical regression to test his hypotheses based on survey data from 104

Italian family firms. He finds support for his hypotheses regarding the respective use of 
knowledge and skills (H1) and cognitive conflict when nonfamily and family CEOs run the family firm. However, the effort of directors has a statistically equal positive influence on board performance regardless of whether the firm is led by a family or nonfamily CEO. His study is important because it helps show not only when different governance configurations are more likely to be successful but how those different configurations can temper the family's willingness and ability to follow idiosyncratic strategies based on a confluence of economic and noneconomic goals. Thus, when nonfamily CEOs are at the helm, the key to good board performance appears to be the willingness of family owners to step back and let the managers manage, while utilizing the knowledge and skills of the board. In contrast, family owners need to allow the board to restrain the unregulated ability of the CEO to call the shots when a family member is in charge.

We see the need for more research on how other characteristics of BODs and board processes influence performance and how different configurations of goals and resources influence the optimal match between board characteristics and board processes. However, the most important research question from Zona's study appears to be: how can CEOs and/or boards influence owners to design a governance structure with enough flexibility to permit effective functioning as the compositions of the top management team and BOD change?

\section{Centralization versus Decentralization}

Martin, McKelvie, and Lumpkin (2016, this issue) suggest that a central challenge of small- and medium-size enterprises (SMEs) is deciding how much authority and responsibility to delegate. Such decisions are especially important to family owners who place great value on the family's ability to control decision making (e.g., Berrone, Cruz, and Gómez-Mejía, 2012; Carney, 2005). Consequently, Martin et al. conduct an exploratory study of centralization and delegation 
practices among a sample of 41 family and 47 nonfamily SMEs located in the southwestern U.S. using a Rasch model, a technique that has rarely been used in management research, to analyze an 11-item Aston studies-based organizational structure scale.

The authors discover two distinct dimensions of decisions that might be centralized or delegated - human resource management decisions and operations management decisions. Their subsequent analysis seeks to determine at which of five organizational levels (from highest to lowest level: BOD/owner; CEO; divisional/functional manager; first-level supervisor; operator/employee) such decisions tend to be made, the idea being that the higher the level the more centralized the decision making and vice versa. Martin et al. find that managing internal labor disputes is the most centralized decision and allocation of work among workers is the most decentralized decision. Overall, they find that decision making in family firms was more centralized than in nonfamily firms. Interestingly, they find systematic differences in the types of decisions that family and nonfamily firms are more likely to delegate. Based on their analysis it appears that family firms are more (less) likely to delegate human resource (operating) decisions than nonfamily firms who prefer to centralize human resource decisions and decentralize operating decisions.

There are several possible reasons for these findings. As suggested by Martin et al. (2016), decentralizing human resource decisions may represent an attempt by family owners to signal that they are committed to professional management practices and eschew biased treatment of nonfamily employees (Verbeke and Kano, 2012). If successful, such signaling efforts can reduce agency costs not only by limiting the potential for moral hazard on the part of disgruntled employees but also by allowing the firm to attract higher quality workers, thus decreasing the potential for adverse selection. However, another reason may simply be that 
family owners are less concerned with who they control than what they control. In other words, given that family owner-managers may first and foremost want to maintain their ability to pursue idiosyncratic strategies that will increase both financial and socioemotional wealth, they focus more on how the business is run than nonfamily owner-managers. This seems to suggest that in terms of governance they emphasize controlling goal achievement over resource development. However, this is only a conjecture; future research is needed to better understand why family and nonfamily firms differ in terms of the decisions that they view as most important to control.

\section{Innovation and Flexibility in Family Firms}

Innovation has emerged as one of the most important topics in the family firm literature but how family involvement influences innovation is not completely clear (Chrisman, Chua, De Massis, Frattini, and Wright, 2015; De Massis, Frattini, and Lichtenthaler, 2013; Kotlar, De Massis, Fang and Frattini, 2014). Broekaert, Andries, and Debackere (2016, this issue) attempt to shed further light on the topic by investigating how family involvement influences R\&D and organizational flexibility and, in turn, how those processes influence firm innovation. Using a path-analytic approach to examine a European Community Innovation Survey sample that includes over 3,140 firm-year observations, Broekaert et al. find that both R\&D and organizational flexibility are positively related to innovation performance measured in terms of the share of sales accruing from product innovation and the cost reduction/quality enhancing effects of process innovation. Importantly, while they find that family firms engage in less R\&D than nonfamily firms, which is consistent with prior literature (e.g., Chrisman and Patel, 2012), they also find that family firms have greater organizational flexibility. According to their results, this translates into equal amounts of product innovation and higher amounts of process innovation for family firms. 
Broekaert et al.’s (2016) study highlights how the willingness and ability of family firms to pursue non-economic goals and idiosyncratic strategies affect governance choices and the development of new resources (De Massis, Kotlar, Chua, and Chrisman, 2014). As they show, family firms prefer not to invest as much in R\&D as nonfamily firms for control (Chrisman and Patel, 2012) and parsimony reasons (Carney, 2005). However, when they decide to innovate for whatever reason (e.g., declining performance, long term orientation) they seem to be able to do so as well and as quickly as nonfamily firms. Prior arguments focused on the discretionary ability of family owners to change focus as the reason. Brockaert et al.'s research contributes new insights by showing that ability of family firms to change is also a function of the manner in which their governance systems are designed. Moreover, their work complements that of Patel and Chrisman (2014) by showing that the willingness dimension of family ownership and management leads not only to exploitative product innovation but also to more process innovation, which further reinforces their focus on existing product-markets.

Further work is still needed though to determine how and why family firms are able to move from exploitative product and process innovation activities to innovation initiatives that are more exploratory in nature. Is it just a function of discretion and flexibility of governance or do differences in goals and resources come into play and if so, how?

\section{Family Firms’ Entry into International Markets}

Rather than focusing on the level of family firm internationalization as in prior studies, Pongelli, Cucculelli, and Caroli (2016, this issue) investigate how family ownership influences foreign market entry. They measure ownership according to the level of family control and the owners' identity and measure entry mode by the level of control the family chooses, i.e., whether they take an equity position in a foreign venture and whether it involves a cooperative alliance with a 
foreign actor. Theoretically, Pongelli et al. rely on the ability and willingness (De Massis et al., 2014) framework. They suggest that family firms with different ownership configurations (founders, multiple family members, multiple families), corresponding to those proposed by Gersick, Davis, Hampton, and Lansberg (1997), will view the value of socioemotional wealth differently and that their ability to act upon their preferences will be a function of the family's share of ownership of the firm.

Pongelli et al. propose that a desire for socioemotional wealth preservation manifests a long-term orientation and a desire for family control, which leads to a preference for foreign market entry modes involving equity ownership without partners (non-cooperative). However, these factors become less important as the number of owners increases and their family ties become weaker. Therefore, founder-owned firms are expected to prefer non-cooperative, equity entry modes and firms owned by multiple families (cousin consortiums) are expected to prefer cooperative, non-equity entry modes. They also propose that the presence of a nonfamily CEO will shift the preferences of the firm toward non-equity, non-cooperative entry modes since the importance owners attach to socioemotional wealth will not be shared by such managers.

Using a sample of 204 family SMEs headquartered in Italy, Pongelli et al.'s (2016) hypotheses are generally supported. Founders are particularly fond of foreign market entry involving equity ownership and they eschew cooperative alliances. In the main, family firms with more dispersed ownership become progressively less likely to share these preferences. Furthermore, the amount of control appears to provide different types of family owners the ability to exercise their preferences. Finally, as expected, the presence of a nonfamily CEO largely tempers the preference of family firms for non-cooperative, equity entry modes. 
Taken together, Pongelli et al.’s (2016) study shows that neither ability nor willingness can be ignored. If family ownership can be considered a type of governance then it is clear that the amount of ownership determines the extent to which the family is able to pursue its goals. However, if one assumes that strategy reflects goals, then Pongelli et al.'s study clearly shows that the goals of owners who drive the strategies of different types of family firms are not uniform and that the presence of important nonfamily actors can have an impact as well. Although these findings are, in some respects obvious, they are important nonetheless given the large number of studies in the family business literature that (in our view mistakenly) assume ability is always accompanied, in general, by willingness and, in particular, by the non-economic goals that lead to socioemotional wealth, which we associate with willingness (cf., Chrisman, Fang, Kotlar, and De Massis, 2015; König et al., 2013; Vardaman and Gondo, 2014). Nevertheless, while Pongelli et al. provide an important contribution by at least indirectly distinguishing how goals and governance lead to different strategic behaviors, there still is the question of how resources fit in. Thus, although it is important to understand what a firm wants to do and how it will do it, we also need to gain a better appreciation of what a firm is capable of doing and how the involvement of a family influences such capability.

\section{Professionalization and Management Buyouts}

Although the tendency in the literature is to consider the inclusion of nonfamily managers in a family firm as synonymous with professionalization, the longitudinal qualitative study of six UK firms undergoing management buy-outs (MBO) or management buy-ins (MBI) by Howorth, Wright, Westhead, and Allcock (2016, this issue) indicates that this is not exactly the case. Indeed, Howorth et al.'s study uses a combination of agency and stewardship theory to show that professionalization is not an event or a threshold but rather a multifaceted process that occurs in 
waves, often caused by changes in ownership and management and tempered by the culture of the firm prior to the MBO or MBI.

Professionalization, according to the authors, involves the institution of management control systems and the formalization of management. In the firms under study, professionalization increased largely because of a decrease in family ownership and management during an MBO or MBI, with the changes more likely in the former than the latter. Despite the divergence of governance structures prior to the buy-out or buy-in, there was a move toward convergence of those structures post-MBO or MBI, along the lines suggested by agency theory. These included changes in personnel and increases in formalization, strategic planning, control processes, participative management, and performance incentives. On the other hand, in the second-half of the 16 year period in which these firms were studied the patterns of change were more diverse with some firms instituting still more control systems and others moving back toward a culture that combined the best elements of a family business and a professionally managed organization.

Overall, the article by Howorth et al. (2016) provides an illustration of the interplay between the ability and willingness of family firms to pursue idiosyncratic goals and strategies through their governance systems and how changes in one affect changes in the other. Family owners that sell out through an MBO or MBI do so either because of declining willingness or because the continued pursuit of non-economic ends become too expensive vis-à-vis their opportunity costs. In either event, by ceding all or part of their ownership and control to nonfamily actors, family stakeholders lose at least some of their ability to shape the future of the firm. This leaves a void that must be filled over time by formal controls because as expressed in classical agency theory, leaving the firm to be directed according to the unfettered ability and 
willingness of managers who are not owners is not a good idea (cf., Fama and Jensen, 1983). Put differently, goals and governance must be compatible; when either or both change, adjustments must be made to re-optimize the two. That takes time because both are embedded in human actions and relationships that are not usually amenable to sudden changes. While this is important information to guide theory and practice, one thing we still do not know is how the adjustments of goals and governance impact (and are impacted by) firm resources and how such adjustments can be accomplished to create rather than destroy competitive advantage.

\section{CONCLUSION}

In conclusion, this introductory article presents a model on how family involvement affects management processes through goals, governance, and resources and report a number of examples on how family firms execute and, thus, build their distinctiveness. These examples include board-CEO interactions, centralization versus delegation, professionalization, internationalization, and innovation. As shown in Table 1, many other aspects remain to be addressed. As scholarly interest concerning family firms continues to grow, we are convinced that gaining a better understanding of management processes and execution will become of crucial importance for research and practice. To this aim, we close this article by offering a sampling of research questions that we believe provide a program for future research on what is a complex and broad direction of study, hoping that our overall effort may represent a starting point for scholarly advancements (see Table 1).

\section{[TABLE 1 HERE]}

\section{ACKNOWLEDGEMENTS}


We are indebted to Jean-Luc Arregle, Cristina Bettinelli, Mara Brumana, Giovanna Campopiano, Allan Discua Cruz, Junsheng Dou, Feranita Feranita, Federico Frattini, Qihai Huang, Marcel Hueslbeck, Peter Jaskiewicz, Carla Jones, Erik Lehmann, Nadine Kammerlander, Josip Kotlar, Antonio Majocchi, Antonio Messeni Petruzzelli, Lucia Naldi, Mattias Nordqvist, Martin Obschonka, Alejandro Rialp Criado, Salvatore Sciascia, Philipp Sieger, Anita van Gils, Wim Voordeckers and Miriam Zschoche who provided valuable assistance as reviewers of the papers submitted to this special issue. 


\section{REFERENCES}

Amis, J., Slack, T., \& Hinings, C. R. (2004). The pace, sequence, and linearity of radical change. Academy of Management Journal, 47(1), 15-39.

Argote, L., \& Greve, H. R. (2007). A behavioral theory of the firm-40 years and counting: Introduction and impact. Organization Science, 18(3), 337-349.

Astrachan, J. H., Klein, S. B., \& Smyrnios, K. X. (2002). The F- PEC scale of family influence: a proposal for solving the family business definition problem. Family Business Review, 15(1), 45-58.

Bammens, Y., Voordeckers, W., \& van Gils, A. (2011). Boards of directors in family businesses: A literature review and research agenda. International Journal of Management Reviews, 13, 134-152.

Berrone, P., Cruz, C., \& Gómez-Mejía, L.R. (2012). Socioemotional wealth in family firms: Theoretical dimensions, assessment approaches, and agenda for future research. Family Business Review, 25, 258-279.

Broekaert, W., Andries, P., \& Debackere, K. (2016, THIS ISSUE). Looking beyond R\&D as enabler of innovation: Family firms’ organizational flexibility advantage. Small Business Economics.

Carney, M. (2005). Corporate governance and competitive advantage in family-controlled firms. Entrepreneurship Theory and Practice, 29, 249-265.

Carnes, C. M., \& Ireland, R. D. (2013). Familiness and innovation: Resource bundling as the missing link. Entrepreneurship Theory and Practice, 37(6), 1399-1419.

Chen, Z. X., \& Aryee, S. (2007). Delegation and employee work outcomes: An examination of the cultural context of mediating processes in China. Academy of Management Journal, 50(1), 226-238.

Chrisman, J.J., Chua, J.H., De Massis, A., Frattini, F., \& Wright, M. (2015). The ability and willingness paradox in family firm innovation. Journal of Product Innovation Management, 32, 310-318.

Chrisman, J. J., Chua, J. H., \& Kellermanns, F. (2009). Priorities, resource stocks, and performance in family and nonfamily firms. Entrepreneurship Theory and Practice, 33(3), 739-760.

Chrisman, J. J., Chua, J. H., Pearson, A. W., \& Barnett, T. (2012). Family involvement, family influence, and family- centered non- economic goals in small firms. Entrepreneurship theory and practice, 36(2), 267-293.

Chrisman, J. J., Chua, J. H., \& Sharma, P. (2005). Trends and directions in the development of a strategic management theory of the family firm. Entrepreneurship theory and practice, 29(5), 555-576.

Chrisman, J.J., Fang, H., Kotlar, J., \& De Massis, A. (2015). A note on family influence and the adoption of discontinuous technologies in family firms. Journal of Product Innovation Management, 32, 384-388.

Chrisman, J.J., \& Patel, P.C. (2012). Variations in R\&D investments of family and nonfamily firms: Behavioral agency and myopic loss aversion perspectives. Academy of Management Journal, 55, 976-997.

Chrisman, J. J., Sharma, P., Steier, L. P., \& Chua, J. H. (2013). The influence of family goals, governance, and resources on firm outcomes. Entrepreneurship Theory and Practice, 37(6), 1249-1261. 
Chrisman, J. J., Steier, L. P., \& Chua, J. H. (2008). Toward a theoretical basis for understanding the dynamics of strategic performance in family firms. Entrepreneurship Theory and Practice, 32(6), 935-947.

Chua, J.H., Chrisman, J.J., \& Bergiel, E.B. (2009). An agency theoretic analysis of the professionalized family firm. Entrepreneurship Theory and Practice, 33, 355-372.

Chua, J.H., Chrisman, J.J., \& De Massis, A. (2015). A Closer Look at Socioemotional Wealth: Its Flows, Stocks, and Prospects for Moving Forward, Entrepreneurship Theory \& Practice, 39(2), 173-182.

Chua, J. H., Chrisman, J. J., Kellermanns, F., \& Wu, Z. (2011). Family involvement and new venture debt financing. Journal of Business Venturing, 26(4), 472-488.

Chua, J. H., Chrisman, J. J., \& Sharma, P. (1999). Defining the family business by behavior. Entrepreneurship: Theory and Practice, 23(4), 19-19.

Chua, J. H., Chrisman, J. J., Steier, L. P., \& Rau, S. B. (2012). Sources of heterogeneity in family firms: An introduction. Entrepreneurship Theory and Practice, 36(6), 1103-1113.

Claessens, S., Djankov, S., \& Lang, L. H. (2000). The separation of ownership and control in East Asian corporations. Journal of Financial Economics, 58(1), 81-112.

Colombo M.G., De Massis A., Piva E., Rossi-Lamastra C., \& Wright M. (2014). Sales and Employment Changes in Entrepreneurial Ventures with Family Ownership: Empirical Evidence from High-tech Industries. Journal of Small Business Management, 52(2), 226245.

De Massis A., Chirico F., Kotlar J., \& Naldi L. (2014). The Temporal Evolution of Proactiveness in Family Firms: The Horizontal S-Curve Hypothesis. Family Business Review, 27(1), 3550.

De Massis A., Di Minin A., \& Frattini F. (2015). Family-driven innovation: Resolving the paradox in family firms. California Management Review, 58(1), 5-19.

De Massis A., Frattini F., \& Lichtenthaler U. (2013). Research on Technological Innovation in Family Firms: Present Debates and Future Directions. Family Business Review, 26(1), 1031.

De Massis, A., Kotlar, J., Chua, J.H., \& Chrisman, J.J. (2014). Ability and willingness as sufficiency conditions for family-oriented particularistic behavior: Implications for theory and empirical studies. Journal of Small Business Management, 52, 344-364.

De Massis, A., Kotlar, J., Frattini, F., Chrisman, J., \& Nordqvist, M. (2016). Family governance at work: Organizing for new product development in family SMEs. Family Business Review, 29, 189-213.

De Massis A., Sharma P., Chua J.H., \& Chrisman J.J. (2012). Family Business Studies: An Annotated Bibliography. Edward Elgar, Cheltenham Glos, UK.

Deephouse, D. L., \& Jaskiewicz, P. (2013). Do family firms have better reputations than non- family firms? An integration of socioemotional wealth and social identity theories. Journal of Management Studies, 50(3), 337-360.

DeTienne, D. R., \& Chirico, F. (2013). Exit strategies in family firms: How socioemotional wealth drives the threshold of performance. Entrepreneurship Theory and Practice, 37(6), 1297-1318.

Fama, E., \& Jensen, M.C. (1983). Separation of ownership and control. Journal of Law and Economics, 26, 301-325. 
Finkelstein, S., \& Hambrick, D. C. (1990). Top-management-team tenure and organizational outcomes: The moderating role of managerial discretion. Administrative Science Quarterly, 484-503.

Gagné M., Sharma P., \& De Massis A. (2014). The Study of Organizational Behavior in Family Business. European Journal of Work and Organizational Psychology, 23(5), 643-656.

George, G., Wiklund, J., \& Zahra, S. A. (2005). Ownership and the internationalization of small firms. Journal of Management, 31(2), 210-233.

Gersick, K.E., Davis, J.A., Hampton, M.M., \& Lansberg, I. (1997). Generation to generation: Life cycles of the family business. Boston, MA: Harvard Business Press.

Gómez-Mejía, L. R., Haynes, K. T., Núñez-Nickel, M., Jacobson, K. J., \& Moyano-Fuentes, J. (2007). Socioemotional wealth and business risks in family-controlled firms: Evidence from Spanish olive oil mills. Administrative Science Quarterly, 52(1), 106-137.

Gomez- Mejia, L. R., Makri, M., \& Kintana, M. L. (2010). Diversification decisions in family- controlled firms. Journal of Management Studies, 47(2), 223-252.

Guidice, R. M., Mero, N. P., \& Greene, J. V. (2013). Perceptions of accountability in family business: Using accountability theory to understand differences between family and nonfamily executives. Journal of Family Business Strategy, 4(4), 233-244.

Habbershon, T. G., Williams, M., \& MacMillan, I. C. (2003). A unified systems perspective of family firm performance. Journal of Business Venturing, 18(4), 451-465.

Hambrick, D. C., \& Finkelstein, S. (1987). Managerial discretion: A bridge between polar views of organizational outcomes. Research in Organizational Behavior.

Hambrick, D. C., \& Mason, P. A. (1984). Upper echelons: The organization as a reflection of its top managers. Academy of Management Review, 9(2), 193-206.

Hitt, M., Ireland, R. D., \& Hoskisson, R. (2012). Strategic management cases: competitiveness and globalization. Cengage Learning: Mason, $\mathrm{OH}$

Howorth, C., Wright, M., Westhead, P., \& Allcock, D. (2016, THIS ISSUE). Becoming a 'proper company': Professionalization waves, family firms and management buyouts. Small Business Economics.

Jennings J.E., Breitkreuz R.S., James A.E. (2013). Theories from family science: A review and roadmap for family business research. In The SAGE Handbook of Family Business, Melin L, Nordqvist, M, Sharma P (eds). SAGE: London, UK: 25-46.

Kellermanns, F.W. (2005). Family firm resource management: Commentary and extensions. Entrepreneurship Theory and Practice, 29, 313-319.

Klein, S. B., Astrachan, J. H., \& Smyrnios, K. X. (2005). The F- PEC scale of family influence: Construction, validation, and further implication for theory. Entrepreneurship Theory and Practice, 29(3), 321-339.

König, A., Kammerlander, N., \& Enders, A. (2013). The family innovator's dilemma: How family influence affects the adoption of discontinuous technologies by incumbent firms. Academy of Management Review, 38, 418-441.

Kotlar J. \& De Massis A. (2013). Goal Setting in Family Firms: Goal Diversity, Social Interactions, and Collective Commitment to Family-Centered Goals. Entrepreneurship Theory \& Practice, 37(6), 1263-1288.

Kotlar J., De Massis, A., Fang H., \& Frattini F. (2014). Strategic Reference Points in Family Firms. Small Business Economics, 43(3), 597-619. 
Kowalewski, O., Talavera, O., \& Stetsyuk, I. (2010). Influence of family involvement in management and ownership on firm performance: Evidence from Poland. Family Business Review, 23, 45-59.

Lane, S., Astrachan, J. H., Keyt, A., \& McMillan, K. S. (2006). Guidelines for family business boards of directors. Family Business Review, 19, 147-167.

Liguori, M. (2012). The supremacy of the sequence: key elements and dimensions in the process of change. Organization studies, 33(4), 507-539.

Litz, R. A. (1995). The family business: Toward definitional clarity. Family Business Review, 8(2), 71-81.

Lorsch, J. W., \& MacIver, E. (1989). Pawns or potentates: The reality of America's corporate boards: Harvard Business School Press. Boston, MA.

Martin, W.L., McKelvie, A., \& Lumpkin, G.T. (2016, THIS ISSUE). Centralization and delegation practices in family versus nonfamily SMEs: A Rasch analysis. Small Business Economics.

Melin, L., Nordqvist, M., \& Sharma, P. (Eds.). (2013). The SAGE handbook of family business. Sage.

Memili, E., Fang, H., Chrisman, J. J., \& De Massis, A. (2015). The impact of small-and mediumsized family firms on economic growth. Small Business Economics, 45(4), 771-785.

Minola, T., Brumana, M., Campopiano, C., Garrett, R., \& Cassia, L. (2017). Corporate Venturing in Family Business: A Developmental Approach of the Enterprising Family, Strategic Entrepreneurship Journal. (forthcoming)

O'Boyle, E. H., Pollack, J. M., \& Rutherford, M. W. (2012). Exploring the relation between family involvement and firms' financial performance: A meta-analysis of main and moderator effects. Journal of Business Venturing, 27(1), 1-18.

Paul, J. J., Winter, M., Miller, N. J., \& Fitzgerald, M. A. (2003). Cross-institutional norms for timing and sequencing and the use of adjustment strategies in families affiliated with family-owned businesses. Marriage \& Family Review, 35(1-2), 167-191.

Patel, P.C., \& Chrisman, J.J. (2014). Risk abatement as a strategy for R\&D investments in family firms. Strategic Management Journal, 35, 617-627.

Patel, P.C., \& Fiet, J.O. (2011). Knowledge combinations and the potential advantages of family firms in searching for opportunities. Entrepreneurship Theory and Practice, 1179-1197.

Pongelli, C., Cucculelli, M., \& Caroli, M.G. (2016, THIS ISSUE). Family business going abroad: A study on family ownership and foreign market entry modes. Small Business Economics.

Romanelli, E., \& Tushman, M. L. (1994). Organizational transformation as punctuated equilibrium: An empirical test. Academy of Management Journal, 37(5), 1141-1166.

Schulze, W. S., Lubatkin, M. H., \& Dino, R. N. (2002). Altruism, agency, and the competitiveness of family firms. Managerial and Decision Economics, 23(4- 5), 247-259.

Schulze, W. S., Lubatkin, M. H., \& Dino, R. N. (2003). Toward a theory of agency and altruism in family firms. Journal of Business Venturing, 18(4), 473-490.

Sharma, P., \& Manikutty, S. (2005). Strategic divestments in family firms: Role of family structure and community culture. Entrepreneurship Theory and Practice, 29, 293-311.

Steier, L. P., Chrisman, J. J., \& Chua, J. H. (2015). Governance Challenges in Family Businesses and Business Families. Entrepreneurship Theory and Practice, 39(6), 1265-1280.

Van de Ven, A.H. (1992). Suggestions for studying strategy process: A research note. Strategic Management Journal, 13(special issue), 169-188. 
Vardaman, J.M., \& Gondo, M.B. (2014). Commentary: Socioemotional wealth conflict in family firms. Entrepreneurship Theory and Practice, 38, 1317-1322.

Verbeke, A., \& Kano, L. (2012). The transaction cost economics theory of the family firm: Family-based human asset specificity and the bifurcation bias. Entrepreneurship Theory and Practice, 36, 1183-1205

Westhead, P., \& Cowling, M. (1998). Family firm research: The need for a methodological rethink. Entrepreneurship: Theory and Practice, 23(1), 31-33.

Wiklund, J., Nordqvist, M., Hellerstedt, K., \& Bird, M. (2013). Internal versus external ownership transition in family firms: an embeddedness perspective. Entrepreneurship Theory and Practice, 37(6), 1319-1340.

Wright, M., Chrisman, J. J., Chua, J. H., \& Steier, L. P. (2014). Family enterprise and context. Entrepreneurship Theory and Practice, 38(6), 1247-1260.

Zahra, S. A., Hayton, J. C., \& Salvato, C. (2004). Entrepreneurship in family vs. Non- Family firms: A Resource- Based analysis of the effect of organizational culture. Entrepreneurship theory and Practice, 28(4), 363-381.

Zellweger, T. M., Eddleston, K. A., \& Kellermanns, F. W. (2010). Exploring the concept of familiness: Introducing family firm identity. Journal of Family Business Strategy, 1(1), 5463.

Zona, F. (2016, THIS ISSUE). CEO leadership and board behaviors in family controlled firms: Comparing family vs. nonfamily CEOs. Small Business Economics. 
TABLE 1 SELECTED QUESTIONS FOR FUTURE RESEARCH ON MANAGEMENT PROCESSES
AND STRATEGY EXECUTION IN FAMILY FIRMS

\begin{tabular}{|c|c|c|}
\hline Building block & Component & Research questions \\
\hline \multirow[t]{6}{*}{ Family involvement } & $\begin{array}{l}\text { Definition of family } \\
\text { involvement }\end{array}$ & $\begin{array}{l}\text { How can family involvement be measured? } \\
\text { Is family involvement unidimensional or } \\
\text { multidimensional? }\end{array}$ \\
\hline & $\begin{array}{l}\text { Effects of family } \\
\text { involvement }\end{array}$ & $\begin{array}{l}\text { How does involvement of nonfamily owners and/or } \\
\text { managers influence the management processes of } \\
\text { family firms? }\end{array}$ \\
\hline & & $\begin{array}{l}\text { Does the family's influence on management processes in } \\
\text { the family firm change with time, especially as later } \\
\text { generations take over? If yes, how and why? }\end{array}$ \\
\hline & & $\begin{array}{l}\text { What are the sources of heterogeneity of the management } \\
\text { processes in family firms? How does family } \\
\text { involvement cause such heterogeneity? }\end{array}$ \\
\hline & External influences & $\begin{array}{l}\text { Do external influences impact how family involvement } \\
\text { influence management processes? }\end{array}$ \\
\hline & & $\begin{array}{l}\text { Do context, culture, and institutional settings have } \\
\text { different effects on management processes in family } \\
\text { and nonfamily firms or different types of family firms? } \\
\text { If yes, how and why? }\end{array}$ \\
\hline \multirow[t]{6}{*}{ Behavioral propensities } & Willingness related & $\begin{array}{l}\text { Do the family members' relationships and interactions in } \\
\text { the family setting affect management processes in the } \\
\text { business setting? If yes, is their impact related to } \\
\text { differences in the willingness to set management } \\
\text { processes? }\end{array}$ \\
\hline & & $\begin{array}{l}\text { Are different degrees of willingness due or related to } \\
\text { different types of family involvement? }\end{array}$ \\
\hline & & $\begin{array}{l}\text { Is the favorable disposition of the involved family } \\
\text { resulting from the family’s motivation and } \\
\text { commitment determined by the family’s beliefs about } \\
\text { the prevailing cultural, political, regulatory, } \\
\text { competitive, and capital market conditions? }\end{array}$ \\
\hline & Ability related & $\begin{array}{l}\text { Do the family members' relationships and interactions in } \\
\text { the family setting affect management processes in the } \\
\text { business setting? If yes, is their impact related to } \\
\text { differences in the ability to set management processes? }\end{array}$ \\
\hline & & $\begin{array}{l}\text { Are different degrees of ability and willingness related to } \\
\text { different types of family involvement? }\end{array}$ \\
\hline & & $\begin{array}{l}\text { Is the family’s organizational authority resulting from the } \\
\text { family's power and legitimacy defined by prevailing } \\
\text { cultural, political, regulatory, competitive, and capital } \\
\text { market conditions? }\end{array}$ \\
\hline \multirow[t]{4}{*}{ Strategic drivers } & Goals related & $\begin{array}{l}\text { How do strategic goals of family firms arise as a result of } \\
\text { the involved family's willingness? }\end{array}$ \\
\hline & & $\begin{array}{l}\text { How do different configurations of goals and resources } \\
\text { influence the optimal match between board } \\
\text { characteristics and board processes? }\end{array}$ \\
\hline & & $\begin{array}{l}\text { Do goals pertaining to the preservation and enhancement } \\
\text { of socioemotional wealth influence the management } \\
\text { processes of family firms? If yes, to which extent? }\end{array}$ \\
\hline & Governance related & How do differences in the family’s ability arising from \\
\hline
\end{tabular}


Resources related

Required tasks

Actors family involvement generate differences in governance?

How do characteristics of boards of directors and board processes influence family and business performance?

How can CEOs and/or boards influence owners to design a governance structure with enough flexibility to permit effective functioning as the composition of the top management team and board of directors change?

Why do family and nonfamily firms differ in terms of the decisions that they view as most important to control?

How can the adjustments of goals and governance be accomplished to create rather than destroy competitive advantage?

How do differences in family involvement generate differences in resources?

How do the adjustments of goals and governance impact (and are impacted by) family firm resources?

How does latitude in strategic decisions concerning how firm resources are developed, deployed, and shed depend on the organizational authority of the involved family?

Execution General

Overall, how do family firms differ from of nonfamily firms in terms of approaches to strategy execution?

When and under what conditions do family dynamics enhance or hinder strategy execution in the family firm? What is the role played by emotions?

How do the five aspects of strategy execution (i.e., required tasks, actors, delegation of tasks, sequence of actions, accountabilities and deliverables) affect each other in the family and nonfamily firms?

How do family firms in different generations face the management challenges associated with strategy execution?

Do management processes emerge, develop, change, or are discarded in different manner by family and nonfamily firms? If yes, how and why?

Do management processes emerge, develop, change, or disappear in a different manner in different types of family firms? If yes, how and why?

How do the noneconomic goals of family firms affect the set of tasks required in order to implement the firm's strategy?

Why and how do the governance structures of family firms influence the set of tasks required to implement the firm's strategy?

Why and how do the resources of family firms influence the set of tasks required to implement the firm's strategy?

How do the changes in family governance over time affect the tasks required to execute firm strategy? How do the tasks required to execute firm strategy change as a result of succession?

Do informal channels of communication among family members affect communication between family and nonfamily managers? If yes, how and why?

Does the heterogeneity of positions and roles of actors 
Delegation of tasks

Sequence of actions within the family system (e.g., offspring, or from other family branches) affect the firm's capability to execute?

Does family governance lead to conservatism in the tasks that are performed, or does it brook less opposition, leading to tasks performed without delay?

Which governance structures should be activated in order to involve nonfamily members in executing organizational actions and tasks?

How do family altruism and emotional attachment affect the effectiveness of different types of actors involved in strategy execution? What are different between family and nonfamily actors and among different types of family actors?

How does information asymmetry between family and nonfamily actors as well as among family actors affect the distribution of decision making processes in the family firm?

How does the level of human capital among family firms affect the effectiveness of delegation processes?

How does the extent of asymmetric family altruism affect the distribution of delegation processes among family and nonfamily actors and the effectiveness of delegation processes?

What specific challenges does the family principals' propensity to keep control in family hands pose for delegation of tasks?

How does leadership and ownership transitions affect delegation processes? What are the differences when the transition involves intra-family succession versus external succession?

Are the processes used to assess the performance of family managers different from those used to assess the performance of nonfamily managers in the same firm? If yes, how and why?

Are family firm managers' performance assessment processes different from those of nonfamily firms? If yes, how and why?

How does the temporal evolution of the family and business systems affect the beliefs, priorities, and goal hierarchies of different family firm actors? How, in turn, does this affect the sequencing of their actions?

Is the temporal sequence of actions influenced by intrafamily succession? If so, how?

Do family versus nonfamily firms prefer to adopt a topdown rather than a bottom-up approach to strategy execution? If yes, why?

Do information processing and task alignment happen differently in family versus nonfamily firms? Is there a propensity of family firms for multitask execution rather than linear and serialized execution? If yes, why? When is multitask execution to be preferred to linear and serialized execution in family firms?

Does implementing radical changes in a family firm require change to start from the more peripheral parts or from the core elements of the family and of the 
Accountabilities and deliverables business?

To what extent do differences in the goals, governance and resource configurations among family firms affect the delegation and sequence of actions required to execute firm strategy?

What are the formal and informal mechanisms and norms through which family firm principals monitor their actors? Does belonging to the family system play a role? If yes, what are the different mechanisms used to monitor family and nonfamily members as well as different types of family members?

Do family firms differ from nonfamily firms in their actors' obligation to report? How does the obligation to report vary among different types of family and nonfamily actors within the family firm?

Do family firms differ from nonfamily firms in the deliverables used for accountability and reporting? How do the objects of accountability adopted by family firms affect the way they undertake information-based controls?

Do disclosure and reporting procedures differ between family and nonfamily firms? If yes, how? Is there any difference when reporting is directed to external versus internal stakeholders?

Who are the managers in family firms accountable to?

How does accountability result in alignment between principals and agents in the family firms?

How do goals, resources, and governance determine the nature and quantity of deliverables a family firm will focus on?

What determines the strength of accountability perception in family firms?

Firm outcomes

How does the heterogeneity of the management processes in family firms influence their economic and noneconomic performance?

What are the implications of different aspects of strategy execution (i.e., required tasks, actors, delegation of tasks, sequence of actions, accountabilities and deliverables) on family firm outcomes?

Is there a feedback loop from Strategy and Execution to the Behavioral Propensities and strategic drivers? How do firm outcomes influence the strategic drivers of family firms (i.e., goals, governance, resources) through feedback loops? 


\section{Figure 1}

How Family Involvement Influences Management Processes by which Family Firms Execute

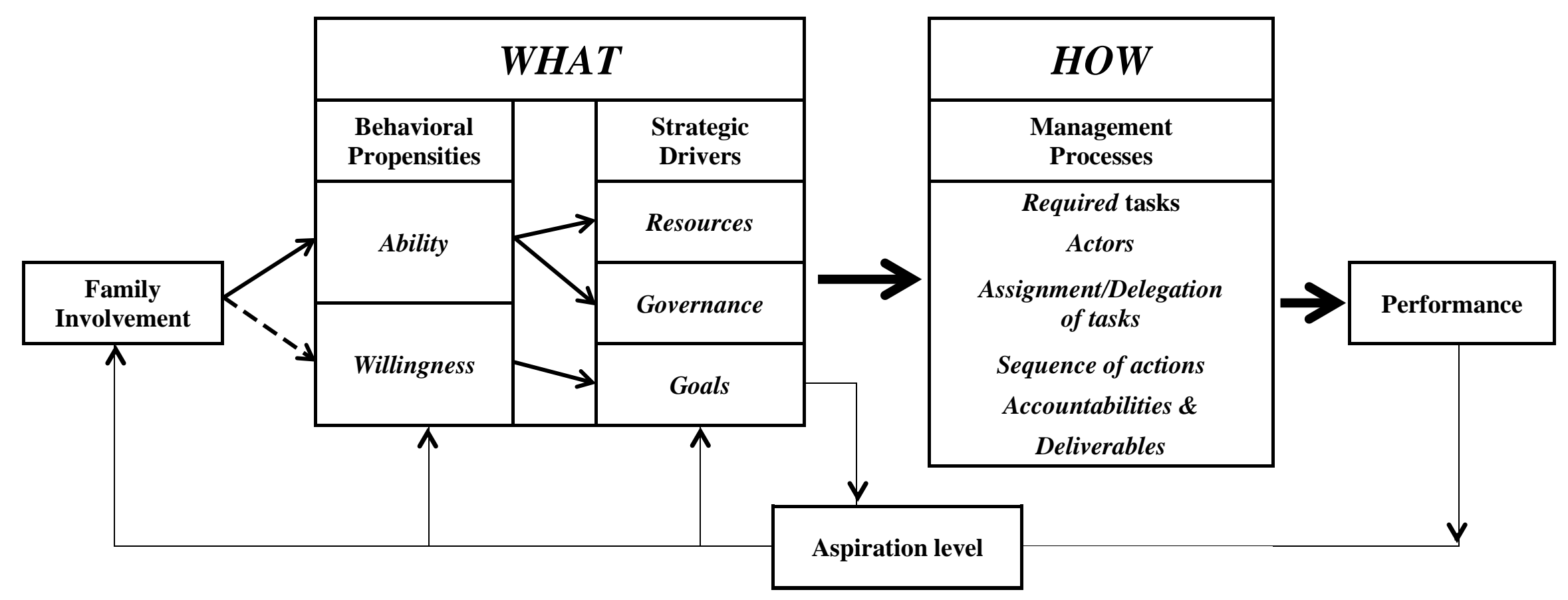

